\title{
Associated Injuries in Patients with Maxillofacial Trauma at the Hospital São Vicente de Paulo, Passo Fundo, Brazil
}

\author{
João Matheus Scherbaum Eidt ${ }^{1}$, Ferdinando De Conto ${ }^{1,2}$, Manoela Moura De Bortoli ${ }^{3}$, Janessa \\ Luiza Engelmann ${ }^{1}$, Franciele Dalamaria Rocha ${ }^{1}$ \\ ${ }^{1}$ School of Dentistry, Universidade de Passo Fundo, Passo Fundo, Brazil. \\ ${ }^{2}$ Department of Oral and Maxillofacial Surgery, Hospital São Vicente de Paulo, Passo Fundo, Brazil. \\ ${ }^{3}$ Department of Oral and Maxillofacial Surgery, Hospital Oswaldo Cruz, Recife, PE, Brazil.
}

\author{
Corresponding Author: \\ Ferdinando de Conto \\ Universidade de Passo Fundo \\ BR 285, Bairro São José \\ 99052-900, Passo Fundo, RS \\ Brazil \\ Phone: +55 5499993113 \\ E-mail: ferdi@upf.br
}

\begin{abstract}
Objectives: This study aimed to identify the occurrence, type and severity of body injuries associated in patients with facial trauma, referred to the Hospital São Vicente de Paulo (HSVP) in the city of Passo Fundo - RS, Brazil. Material and Methods: The study analyzed medical records of 1385 patients who were treated in the Department of Oral and Maxillofacial Surgery at HSVP during the period from 1991 to 2010.

Results: According to the results of this study we observed that $35 \%$ of cases of facial fractures were associated with a body injury. It was recorded a higher incidence of facial fractures in the male population (82.6\%), aged between 20 and 39 years. The main etiologic factors for this association were car accidents, falls and assaults. Most fractures were recorded in the mandible and the main body injury found was the abrasion associated in some region of the body, however, when considering fractures of the face middle third the main body injury was more associated with cranioencephalic trauma.

Conclusions: Concomitant injuries in areas other than the face should be expected first and foremost after highspeed trauma mechanisms and in association with severe facial fractures. The results underscore the importance of multiprofessional collaboration in diagnosis and sequencing of treatment who have sustained facial fractures.
\end{abstract}

Keywords: maxillofacial injuries; traumatology; multiple trauma; epidemiology.

Accepted for publication: 7 September 2013

To cite this article:

Scherbaum Eidt JM, De Conto F, De Bortoli MM, Engelmann JM, Rocha FD. Associated Injuries in Patients with Maxillofacial Trauma at the Hospital São Vicente de Paulo, Passo Fundo, Brazil.

URL: http://www.ejomr.org/JOMR/archives/2013/3/e1/v4n3e1ht.pdf

doi: $10.5037 /$ jomr.2013.4301 


\section{INTRODUCTION}

Facial trauma may be considered one of the most significant aggressions found in trauma centres due to the emotional consequences, the possibility of deformation, and the economical impact it causes in the health system [1]. Because of little protection and considerable exposure of the facial region, a great number of severe facial lesions often occur. Head and face lesions may represent $50 \%$ of all traumatic deaths [2].

Maxillofacial fractures are more predominant in big cities due to intense traffic and high violence rate. The causes, types, and sites of fractures vary. Different studies have shown the relationship between maxillofacial fractures, gender, age, and level of urban development [2-5]. As man evolved and developed more machinery to ease day to day living, the incidence and severity of trauma injuries to the face also increased [6]

When trying to outline the epidemiological profile of facial traumas all over the world, many studies were carried out correlating social, urban, and rural changes as modifying agents of interpersonal relations, generating acts of physical violence both personal and collective, which are represented by interpersonal violence, traffic violence, domestic violence, and violence against women [6].

Men are more exposed to the trauma due to the greater number of automobile drivers, the practice of physical contact sports, in addition to a more intense social life inferring in higher consumption of alcohol and other drugs [7]. In turn, some affirm that, especially over the last three decades, there has been a growing increase of traumas in women usually around 40 years old due to their increasing participation in activities that were previously male dominant [5].

Many studies show that, for children and the elderly, facial fractures are associated with either falls at home, or children's games and activities [ $[\underline{5,}, \underline{8-10}]$.

Considering the clinical aspects of the trauma, the high rate of complex nasal fractures and zygomatic orbital fractures are obviously related to the prominent position of these anatomical structures inside the facial skeleton, and their greater exposure to the external trauma $[11,12]$. Added to the facial trauma, it is possible to identify associated injuries and classify six organ systems related to these lesions: 1) brain, 2) chest, 3) abdomen, 4) pelvis, 5) spine, 6) limbs. There are considerable statistical differences in the occurrence of injuries associated among gender, age group, trauma mechanism, and type of fracture. The mechanism of these traumas may be through automobile accidents, falls, interpersonal violence, sports, and victims hit with objects [13].

Hands and arms are usually used by patients victims of trauma as protection against a facial lesion, while legs and thorax are usually directly impacted in car accidents or falls [14].

The purpose of the present study was to identify the occurrence, types, and severity of associated injuries outside the facial region in patients diagnosed with facial fractures at Hospital São Vicente de Paulo, Passo Fundo, Brazil.

\section{MATERIAL AND METHODS}

This is a cross-sectional, retrospective observational study, which criteria was the inclusion of all medical records of patients with history of facial fracture assisted in the department of Oral and Maxillofacial Surgery of Hospital São Vicente de Paulo - Passo Fundo, Brazil, along with the department of Medical File and Statistical Service. The period established was ten years, starting on January $1^{\text {st }}, 2001$ and ending on December $31^{\text {st }}, 2010$.

Data evaluated considered the etiological agent of the lesion, precedence, age, and gender of the patient as well as the site of fractures. Patients with lesions exclusive to soft tissues of the face were not included in the study. The traumatic injuries associated to facial fractures were classified according to the different types [13].

To analyze data, the medical records were divided according to the patients' age group, in dozens. Patients were divided by male and female gender. Regarding precedence, the referential point was the city of Passo Fundo, and the classification "other locations" was assigned to patients from other cities due to the influence Passo Fundo has regionally, especially concerning health centres.

The etiological agents were divided in seven groups: interpersonal violence, fall, automobile accidents, sports accidents, work accidents, others and when it was not described, this was classified as not informed. Lesions by firearm, domestic violence, assaults, and physical fighting are included in the item "interpersonal violence". Included in the item "automobile accidents" are: being run over by motorcycles, bicycles, and automobiles. The group entitled "others" covers accidents with animals and removal of impacted teeth. The distribution of fractures site was divided in eight groups: zygoma, mandible, orbit, nose, maxilla, Le Fort (I, II, and III) naso-orbital-ethmoid and dentoalveolar fractures. The three types of Le Fort fracture were joined in one single item because of the few cases diagnosed. 
According to Thorén et al. [9], the injuries associated to facial trauma were classified and divided by: upper limb, lower limb, skull, cranioencephalic trauma (CET), thorax, spine, skin excoriation, and abdomen. Cases with no injuries were included in the group "absent".

The project was submitted and approved by the Research Ethics Committee of the Hospital São Vicente de Paulo - Passo Fundo/RS, and by the committee of the University of Passo Fundo (UPF).

The tabulated data were statistically analyzed using a chi-square test with significance level of 5\% followed by the Pearson's correlation test in the program SPSS version 20 .

\section{RESULTS}

The analysis of patients, who suffered maxillofacial trauma in this study from 2001 to 2010 , resulted in 1385 clinical medical records of different patients, recording a higher frequency of facial fractures in the age group between 20 and 39 years old. Patients aged between 10 and 19 years old, and 40 and 49 years old also presented high rates of maxillofacial fracture occurrence, and this rate was higher in the male population $(82.6 \%)$ for all age groups (Table 1).

Passo Fundo - RS, considered reference for trauma in the northeast region of the state of Rio Grande do Sul, Brazil, presented lower frequency (35.2\%) of facial traumas, which were more common in patients from nearby cities $(64.8 \%)$. The most common etiological agent among the analyzed cases was automobile accident $(25.8 \%)$, followed by interpersonal violence and fall. The classification "not informed" obtained considerable numbers $(22.3 \%)$ due to failure to fill this item in the medical records (Table 1).

The most common affected site of facial fractures verified was mandibular fractures $(34.7 \%)$, followed by zygomatic bone fractures (24\%), and nose (22.8\%). Injuries associated to facial trauma presented skin excoriation (15.7\%) as main injury, followed by CET $(12.8 \%)$. Within the researched items, it is demonstrated that human body injuries associated to the patient victim of facial trauma occurred in about $35 \%$ of the cases (Table 1).

The correlation statistical analysis among the age group of patients who suffered associated body injuries revealed to be more relevant in the age group from 20 to 39 years old, adding 260 cases, followed by 10 to 19 years old (64 cases), and 40 to 49 years old (74 cases). The most named injury was skin excoriation followed by CET (Table 2).

It is possible to verify that among all medical records analyzed (1,385), 506 cases of body injuries
Table 1. Description of statistics of the studied population

\begin{tabular}{|c|c|c|}
\hline & $\mathbf{N}$ & $\%$ \\
\hline \multicolumn{3}{|l|}{ Gender } \\
\hline Male & 1144 & $82.6 \%$ \\
\hline Female & 241 & $17.4 \%$ \\
\hline \multicolumn{3}{|l|}{ Age groups } \\
\hline $0-9$ & 69 & $5.0 \%$ \\
\hline $10-19$ & 214 & $15.5 \%$ \\
\hline $20-29$ & 396 & $28.6 \%$ \\
\hline $30-39$ & 302 & $21.8 \%$ \\
\hline $40-49$ & 212 & $15.3 \%$ \\
\hline $50-59$ & 106 & $7.7 \%$ \\
\hline $60-69$ & 50 & $3.6 \%$ \\
\hline $70-79$ & 26 & $1.9 \%$ \\
\hline $80-89$ & 10 & $0.7 \%$ \\
\hline \multicolumn{3}{|l|}{ Precedence } \\
\hline Passo Fundo & 487 & $35.2 \%$ \\
\hline Other locations & 898 & $64.8 \%$ \\
\hline \multicolumn{3}{|l|}{ Etiological agents } \\
\hline Automobile accidents & 358 & $25.8 \%$ \\
\hline Interpersonal violence & 302 & $21.8 \%$ \\
\hline Fall & 253 & $18.3 \%$ \\
\hline Work accidents & 33 & $2.4 \%$ \\
\hline Sport accidents & 56 & $4 \%$ \\
\hline Others & 74 & $5.3 \%$ \\
\hline Not informed & 309 & $22.3 \%$ \\
\hline \multicolumn{3}{|l|}{ Affected site } \\
\hline Zygoma & 332 & $24 \%$ \\
\hline Mandible & 481 & $34.7 \%$ \\
\hline Orbit & 238 & $17.2 \%$ \\
\hline Nose & 316 & $22.8 \%$ \\
\hline Maxilla & 78 & $5.6 \%$ \\
\hline Le Fort & 139 & $10 \%$ \\
\hline NOE & 68 & $4.9 \%$ \\
\hline Dentoalveolar fractures & 36 & $2.6 \%$ \\
\hline \multicolumn{3}{|l|}{ Injuries associated } \\
\hline Upper limb & 37 & $2.7 \%$ \\
\hline Lower limb & 39 & $2.8 \%$ \\
\hline Cranioencephalic trauma & 177 & $12.8 \%$ \\
\hline Thorax & 21 & $1.5 \%$ \\
\hline Spine & 11 & $0.8 \%$ \\
\hline Skin excoriations & 217 & $15.7 \%$ \\
\hline Abdomen & 4 & $0.3 \%$ \\
\hline Absent & 910 & $65.7 \%$ \\
\hline
\end{tabular}

$\mathrm{N}=$ number of patients; $\mathrm{NOE}=$ naso-orbital-ethmoid.

associated to facial trauma were processed. Yet, in all of these cases, the most evident etiological agent was "automobile accident" representing 201 of the cases (39.7\%), followed by "fall" (20.9\%), and "interpersonal violence" (17.9\%). The most evident injuries in relation to all types of etiological agents are skin excoriation 
Table 2. Distribution of injuries location depending on the patients' age

\begin{tabular}{c|c|c|c|c|c|c|c|c}
\hline \multicolumn{10}{c}{ Injuries (n/\%) } \\
\hline Age groups & UL & LL & CET & Thorax & Spine & $\begin{array}{c}\text { Skin } \\
\text { excoriations }\end{array}$ & Abdomen & Total \\
\hline $\mathbf{0}-\mathbf{9}$ & $2 / 2.9$ & $3 / 4.3$ & $20 / 29$ & $1 / 1.4$ & $0 / 0$ & $11 / 15.9$ & $0 / 0$ & $37 / 7.3 \%$ \\
\hline $\mathbf{1 0}-\mathbf{1 9}$ & $3 / 1.4$ & $5 / 2.3$ & $23 / 10.7$ & $4 / 1.9$ & $0 / 0$ & $29 / 13.6$ & $0 / 0$ & $64 / 12.6 \%$ \\
\hline $\mathbf{2 0}-\mathbf{2 9}$ & $11 / 2.8$ & $12 / 3$ & $51 / 12.9$ & $7 / 1.8$ & $3 / 0.8$ & $61 / 15.4$ & $1 / 0.3$ & $146 / 28.8 \%$ \\
\hline $\mathbf{3 0}-\mathbf{3 9}$ & $8 / 2.6$ & $9 / 3$ & $28 / 9.3$ & $6 / 2$ & $3 / 1$ & $58 / 19.2$ & $2 / 0.7$ & $114 / 22.5 \%$ \\
\hline $\mathbf{4 0}-\mathbf{4 9}$ & $7 / 3.3$ & $8 / 3.8$ & $31 / 14.6$ & $1 / 0.5$ & $2 / 0.9$ & $25 / 11.8$ & $0 / 0$ & $74 / 14.6 \%$ \\
\hline $\mathbf{5 0}-\mathbf{5 9}$ & $3 / 2.8$ & $1 / 0.9$ & $14 / 13.2$ & $0 / 0$ & $2 / 1.9$ & $14 / 13.2$ & $1 / 0.9$ & $35 / 7 \%$ \\
\hline $\mathbf{6 0}-\mathbf{6 9}$ & $1 / 2$ & $0 / 0$ & $4 / 8$ & $1 / 2$ & $1 / 2$ & $10 / 20$ & $0 / 0$ & $17 / 3.4 \%$ \\
\hline $\mathbf{7 0}-\mathbf{7 9}$ & $2 / 7.7$ & $1 / 3.8$ & $5 / 19.2$ & $0 / 0$ & $0 / 0$ & $7 / 26.9$ & $0 / 0$ & $15 / 3 \%$ \\
\hline $\mathbf{8 0}-\mathbf{8 9}$ & $0 / 0$ & $0 / 0$ & $1 / 10$ & $1 / 10$ & $0 / 0$ & $2 / 20$ & $0 / 0$ & $4 / 0.8 \%$ \\
\hline Total of injuries & 37 & 39 & 177 & 21 & 11 & 217 & 4 & 506 \\
\hline Grand total (injuries) & & & & $506 / 100 \%$ & & \\
\hline
\end{tabular}

$\mathrm{n}=$ number of patients; $\mathrm{UL}=$ upper limb; $\mathrm{LL}=$ lower limb; $\mathrm{CET}=$ cranioencephalic trauma.

Table 3. Distribution of injuries location depending on the etiological agent

\begin{tabular}{l|c|c|c|c|c|c|c|c}
\hline \multicolumn{1}{c}{ Injuries (n/\%) } \\
\hline Etiological agent & UL & LL & CET & Thorax & Spine & $\begin{array}{c}\text { Skin } \\
\text { excoriation }\end{array}$ & Abdomen & Total \\
\hline Automobile accidents & $21 / 5.9$ & $26 / 7.3$ & $65 / 18.2$ & $10 / 2.8$ & $5 / 1.4$ & $73 / 20.4$ & $1 / 0.3$ & $201 / 39.7 \%$ \\
\hline Interpersonal violence & $4 / 1.3$ & $2 / 0.7$ & $34 / 11.3$ & $4 / 1.3$ & $1 / 0.3$ & $46 / 15.2$ & $0 / 0$ & $91 / 18 \%$ \\
\hline Fall & $9 / 3.6$ & $5 / 2$ & $39 / 15.4$ & $2 / 0.8$ & $3 / 1.2$ & $48 / 19$ & $0 / 0$ & $106 / 21 \%$ \\
\hline Work accidents & $0 / 0$ & $0 / 0$ & $3 / 9.1$ & $0 / 0$ & $0 / 0$ & $3 / 9.1$ & $0 / 0$ & $6 / 1.2 \%$ \\
\hline Sport accidents & $0 / 0$ & $0 / 0$ & $3 / 5.4$ & $1 / 1.8$ & $0 / 0$ & $7 / 12.5$ & $0 / 0$ & $11 / 2.1 \%$ \\
\hline Others & $1 / 1.4$ & $2 / 2.7$ & $8 / 10.8$ & $4 / 5.4$ & $1 / 0.3$ & $19 / 25.7$ & $3 / 4.1$ & $38 / 7.5 \%$ \\
\hline Not informed & $2 / 0.6$ & $4 / 1.3$ & $25 / 8.1$ & $0 / 0$ & $1 / 0.3$ & $21 / 6.8$ & $0 / 0$ & $53 / 10.5 \%$ \\
\hline Total of injuries & 37 & 39 & 177 & 21 & 11 & 217 & 4 & 506 \\
\hline Grand total (injuries) & \multicolumn{7}{|c|}{} & \multicolumn{7}{|c|}{$506 / 100 \%$} & & &
\end{tabular}

$\mathrm{n}=$ number of patients; $\mathrm{UL}=$ upper limb; $\mathrm{LL}=$ lower limb; CET $=$ cranioencephalic trauma.

representing 217 of the cases $(15.7 \%)$, followed by CET $(12.8 \%)$ (Table 3).

From the 1385 patients originally studied, the affected site that mostly showed facial fractures was the mandible representing 481 of the cases, followed by zygomatic trauma, and then the nasal. Relating this data with injuries associated to facial trauma it is possible to conclude that skin excoriation was the most present injury in this study in practically all types of facial fracture. It is observed that in facial traumas in the midface of naso-orbital-ethmoid, Le Fort, and orbit types, the most associated injury was CET (Table 4).

When analyzing the patients' gender most affected by injuries associated to facial trauma, men prevailed representing 424 (37\%) injuries from 1144 cases. Injuries that most affected this population were skin excoriation (16\%), followed by CET (13\%) (Table 5). There was no statistically significant change between the different variables.

\section{DISCUSSION}

With the analysis of 1385 medical records of patients with facial trauma, assisted at the Hospital São Vicente de Paulo in the city of Passo Fundo - RS, Brazil, it is possible to observe that most of them are male (82.6\%). A study that analyzed 9543 patients with facial trauma allowed verifying a frequency of the male gender in these accidents with a proportion, mentioned by authors, of 2:1 male patients injured $(n=6474)$ [15]. Other studies also confirmed the prevalence of the male gender in facial trauma $[\underline{15}, \underline{19}]$.

Patients from this study in the age group from 20 to 40 years old presented a higher frequency of facial trauma (260 cases) and associated body injuries. Age groups between 20 and 49 years old are the most common relating to facial trauma; automobile accident and interpersonal violence are the most frequent agents 
Table 4. Distribution of injuries location depending on the affected sites

\begin{tabular}{l|c|c|c|c|c|c|c|c}
\hline \multicolumn{1}{c|}{ Affected sites } & UL & LL & CET & Thorax & Spine & $\begin{array}{c}\text { Skin } \\
\text { excoriation }\end{array}$ & Abdomen & Total \\
\hline Zygoma & $4 / 1.2$ & $7 / 2.1$ & $31 / 9.3$ & $1 / 0.3$ & $0 / 0$ & $43 / 13$ & $1 / 0.3$ & $87 / 17.2 \%$ \\
\hline Mandíble & $20 / 4.2$ & $13 / 2.7$ & $43 / 0.9$ & $13 / 2.7$ & $4 / 0.8$ & $67 / 13.9$ & $2 / 0.4$ & $162 / 32 \%$ \\
\hline Orbit & $5 / 2.1$ & $11 / 4.6$ & $45 / 18.9$ & $2 / 0.8$ & $0 / 0$ & $39 / 16.4$ & $1 / 0.4$ & $103 / 20.3 \%$ \\
\hline Nose & $4 / 1.3$ & $4 / 1.3$ & $27 / 8.5$ & $3 / 0.9$ & $2 / 0.6$ & $55 / 17.4$ & $0 / 0$ & $95 / 18.8 \%$ \\
\hline Maxilla & $2 / 2.6$ & $4 / 5.1$ & $7 / 9$ & $2 / 2.6$ & $0 / 0$ & $24 / 30.8$ & $0 / 0$ & $39 / 7.7 \%$ \\
\hline Le Fort & $2 / 1.4$ & $6 / 4.3$ & $28 / 20.1$ & $2 / 1.4$ & $3 / 2.2$ & $22 / 15.8$ & $0 / 0$ & $63 / 12.4 \%$ \\
\hline NOE & $3 / 4.4$ & $1 / 1.5$ & $37 / 54.4$ & $1 / 1.5$ & $2 / 2.9$ & $9 / 13.2$ & $1 / 1.5$ & $54 / 10.7 \%$ \\
\hline Dentoalveolar & $0 / 0$ & $3 / 8.3$ & $2 / 5.6$ & $0 / 0$ & $0 / 0$ & $8 / 22.2$ & $0 / 0$ & $13 / 2.5 \%$ \\
\hline Total of injuries & 40 & 49 & 220 & 24 & 11 & 267 & 5 & $616 / 100 \%$ \\
\hline Total of fractures & \multicolumn{70}{|c|}{$1688 / 100 \%$} & & & \\
\hline
\end{tabular}

$\mathrm{n}=$ number of patients; $\mathrm{NOE}=$ naso-orbital-ethmoid; $\mathrm{UL}=$ upper limb; $\mathrm{LL}=$ lower limb; $\mathrm{CET}=$ cranioencephalic trauma.

Table 5. Distribution of injuries location depending on the gender

\begin{tabular}{l|c|c|c|c|c|c|c|c}
\hline \multicolumn{1}{c}{ Gender } & UL & LL & CET & Thorax & Spine & $\begin{array}{c}\text { Skin } \\
\text { excoriation }\end{array}$ & Abdomen & Total \\
\hline Male & $32 / 2.8 \%$ & $31 / 2.7 \%$ & $149 / 13 \%$ & $15 / 1.3 \%$ & $10 / 0.9 \%$ & $183 / 16 \%$ & $4 / 0.3 \%$ & $424 / 83.8 \%$ \\
\hline Female & $5 / 2.1 \%$ & $8 / 3.3 \%$ & $28 / 11.6 \%$ & $6 / 2.5 \%$ & $1 / 0.4 \%$ & $34 / 14.1 \%$ & $0 / 0 \%$ & $82 / 16.2 \%$ \\
\hline Grand total (injuries) & \multicolumn{7}{c}{$506 / 100 \%$} \\
\hline
\end{tabular}

$\mathrm{n}=$ number of patients; $\mathrm{UL}=$ upper limb; $\mathrm{LL}=$ lower limb; CET = cranioencephalic trauma.

causing these fractures, still regarding the present study [16]. The average age of patients with associated body injuries of the studied population was of 29.8 years old, once again in favour of the results of the present study [17].

The most prevalent etiological agent that caused body injury associated to facial trauma was automobile accident $(39.7 \%)$. In this study, the second cause was interpersonal violence that represented $17.9 \%$ of the cases of body injuries associated to facial trauma. A study that analyzed 325 patients showed that car accidents are responsible for about $2 / 5$ of body injuries associated to facial trauma, followed by interpersonal violence (17\%) [17].

Interpersonal violence, which can be framed in the matter of urban violence, is associated to emotional and socioeconomic conflicts, especially among younger population. Relating to facial trauma, reducing interpersonal violence will be more complicated than, for example, decrease these occurrences for automobile accidents, because the tendency of urban violence and social conflicts is to increase. The lack of investments from the government in education and public safety concerns and worsens this situation even more.

An automobile accident causes a more random pattern of mechanical trauma, with forces distributed to the entire body, which is conducive to injury to multiple parts of the body. Based on the results of the present study, concomitant injuries in areas other than the face in patients with facial fractures should be expected first and foremost in connection with high-speed trauma mechanisms and in association with severe facial injuries. Trauma that involves sufficient energy to fracture the bones of the facial skeleton is also likely to distribute a substantial amount of force to other parts of the body, and thus cause injury $[\underline{8}, 9]$.

Road traffic accidents are the leading cause for the maxillofacial fractures. The reasons for this high frequency are difficult to postulate but may be due to the factors mentioned below. Inadequate road safety awareness, unsuitable road conditions without expansion of the motorway network, violation of speed limits, old vehicles without safety features such as antiburst locks and energy absorbing materials, failure to wear seat belts or helmets, entry in to opposite traffic lane, violation of the right of the way, violation of the highway code, use of alcohol or other intoxicating agents, behavioural disorders and socio-economical insufficiencies of some drivers [4]

The most prevalent affected site was the mandible 
representing 481 of the cases, followed by zygomatic and nasal. These sites are featured mainly because they are prominent within the facial skeleton and more exposed to the external trauma [12]. Studies showed high rates of car accidents that tend to present mandible fracture as most frequent fracture site $[14,18]$. The zygoma prevailed in 332 of the cases, standing as second most affected site.

When compared to the previous study [7], in the same location between 1999 and 2000, these data revealed some disagreements, both in the frequency of most affected face site - in the occasion, the zygomatic and in the difference between automobile accident and interpersonal violence - greater in the previous study. This differences are mainly due to the different time period analyzed, and above all it is observed a decrease in the rate of facial fractures occurred by automobile accident and an increase of interpersonal violence as etiological factor. These data may suggest a greater awareness by the local population regarding traffic risks.

Preventive measures, such as the obligatory wearing of a crash helmet and seat belts, better enforcement of the law regarding "drinking and driving", educating people about the dangers of all-terrain injuries and providing proper safety guidelines before the purchase of a vehicle have been shown to significantly reduce the number of road traffic accidents [4].

The nasal region was the most compromised in studies that evaluated victims of car accidents, and analyzed victims of interpersonal violence. Thus, it is possible to affirm that different traumatic etiological agents may lead to lesions with similar aspects and distributions [20].

The injury associated to facial trauma mostly found in this study were skin excoriation, totalizing 267 of 616 injuries from the total of 1688 fractures in the group of 1385 patients, followed by CET, which totalized 220 cases. On the other hand, it was reported in literature that $55 \%$ of 200 patients with facial fracture had CET [21].

In a retrospective study that analyzed 42 patients with naso-orbital-ethmoid fractures, in the period from January 1987 to March 2002, it is possible to assess that the risk group for these fractures is composed by male individuals, from 21 to 40 years old, particularly involved in automobile accidents, and that the main associated injury was the CET [22].

Facial lesions in 580 patients who presented 935 mandibular fractures determined that $46.6 \%$ of these fractures were associated to lesions in soft tissues, with prevalence of head injuries, facial laceration (29.8\%), and ocular lesions (5.7\%) [19].

The epidemiological investigation of facial traumas along with associated body injuries enables the outlining of risk circumstances, as well as the characteristics of individuals who are more susceptible to facial trauma in the city of Passo Fundo and nearby region.

This study also allowed assessing the most affected facial fractures sites, as well as identifying the body injuries associated to this trauma. Lesions in other parts of the body must not be forgotten. The maxillofacial surgeon who performs the emergency service must be aware of the fact that about $25 \%$ of patients with facial fractures have lesions in other parts of the body, after all, this is the professional who is in the front line performing the primary evaluation of patients who suffered fractures in the facial bones [13]. In this study, $36.5 \%$ of body injuries associated to facial trauma were found. The prevalence of concomitant injuries in this series serves as a reminder of the acuity of these patients and the importance of a multidisciplinary approach to the trauma patient $[\underline{8}, \underline{9}]$.

\section{CONCLUSIONS}

According to the results of this work, it was possible to verify and conclude that in $35 \%$ of the cases of facial fracture there was an associated body injury. Male individuals from 20 to 40 years old were the most affected. The main etiological factors for this association were automobile accidents, falls, and interpersonal violence. Most fractures were mandibular, and the main associated body injury observed were skin excoriation, however, when considered the fractures of the middle third the main associated body injury were traumatic brain injuries. Concomitant injuries in areas other than the face should be expected first and foremost after high-speed trauma mechanisms and in association with severe facial fractures. The results underscore the importance of multiprofessional collaboration in diagnosis and sequencing of treatment who have sustained facial fractures.

\section{ACKNOWLEDGMENTS AND DISCLOSURE STATEMENTS}

The authors report no conflicts of interest related to this study. The authors would like to thank Iris Penz (Hospital São Vicente de Paulo, Passo Fundo, Brazil) for your help in editing this manuscript. 


\section{REFERENCES}

1. Wulkan M, Parreira JG Jr, Botter DA. [Epidemiology of facial trauma]. Ver Assoc Med Bras. 2005 Sep-Oct;51(5):290-5. Epub 2005 Oct 31. Portuguese. [Medline: 16270148] [doi: 10.1590/S0104-42302005000500022] [FREE Full Text]

2. MacKenzie EJ. Epidemiology of injuries: current trends and future challenges. Epidemiol Rev. 2000;22(1):112-9. Review. [Medline: 10939015] [doi: 10.1093/oxfordjournals.epirev.a018006] [FREE Full Text]

3. Erdmann D, Follmar KE, Debruijn M, Bruno AD, Jung SH, Edelman D, Mukundan S, Marcus JR. A retrospective analysis of facial fracture etiologies. Ann Plast Surg. 2008 Apr;60(4):398-403. [Medline: 18362568] [doi: 10.1097/SAP.0b013e318133a87b]

4. Naveen Shankar A, Naveen Shankar V, Hegde N, Sharma, Prasad R. The pattern of the maxillofacial fractures - A multicentre retrospective study. J Craniomaxillofac Surg. 2012 Dec;40(8):675-9. Epub 2011 Dec 31. [Medline: 22212823] [doi: 10.1016/j.jcms.2011.11.004]

5. Kostakis G, Stathopoulos P, Dais P, Gkinis G, Igoumenakis D, Mezitis M, Rallis G. An epidemiologic analysis of 1,142 maxillofacial fractures and concomitante injuries. Oral Surg Oral Med Oral Pathol Oral Radiol. 2012 Nov;114(5 Suppl):S69-73. Epub 2012 Feb 28. [Medline: 23083959] [doi: 10.1016/j.tripleo.2011.08.029]

6. Kamulegeya A, Lakor F, Kabenge K. Oral maxillofacial fractures seen at a Ugandan tertiary hospital: a six-month prospective study. Clinics (Sao Paulo). 2009;64(9):843-8. [Medline: 19759877] [doi: 10.1590/S1807-59322009000900004] [FREE Full Text]

7. De Conto F, Dos Santos R S, Rhoden R, Nicolini IC. Levantamento epidemiológico das fraturas de face no hospital São Vicente de Paulo, Passo Fundo, RS. Revista da Faculdade de Odontologia - UPF. 2003;8(2):81-82. URL: http://www.upf. br/seer/index.php/rfo/article/view/1225

8. Follmar KE, Debruijn M, Baccarani A, Bruno AD, Mukundan S, Erdmann D, Marcus JR. Concomitant injuries in patients with panfacial fractures. J Trauma. 2007 Oct;63(4):831-5. [Medline: 18090013] [doi: 10.1097/TA.0b013e3181492f41]

9. Thorén H, Schaller B, Suominen AL, Lindqvist C. Occurrence and severity of concomitant injuries in other areas than the face in children with mandibular and midfacial fractures. J Oral Maxillofac Surg. 2012 Jan;70(1):92-6. Epub 2011 Sep 29. [Medline: 21958660] [doi: 10.1016/i.joms.2011.06.227]

10. Schaller B, Hosokawa S, Büttner M, Iizuka T, Thorén H. Occurence, types and severity of associated injuries of paediatric patients with fractures of the frontal skull base. J Craniomaxillofac Surg. 2012 Oct;40(7):e218-21. Epub 2011 Nov 9. [Medline: 22078497] [doi: 10.1016/j.jcms.2011.10.028]

11. Lee KH, Snape L, Steenberg LJ, Worthington J. Comparison between interpersonal violence and motor vehicle accidents in the aetiology of maxillofacial fractures. ANZ J Surg. 2007 Aug;77(8):695-8. [Medline: 17635287] [doi: 10.1111/j.1445-2197.2007.04189.x]

12. Eggensperger N, Smolka K, Scheidegger B, Zimmermann H, lizuka T. A 3-year survey of assault-related maxillofacial fractures in central Switzerland. J Craniomaxillofac Surg. 2007 Apr;35(3):161-7. Epub 2007 Jun 20. [Medline: 17583524] [doi: $10.1016 /$ j.jcms.2007.01.002]

13. Thorén H, Snäll J, Salo J, Suominen-Taipale L, Kormi E, Lindqvist C, Törnwall J. Occurrence and Types of Associated Injuries in Patients With Fractures of the Facial Bones. J Oral Maxillofac Surg. 2010 Apr;68(4):805-10. Epub 2010 Jan 15. [Medline: 20079962] [doi: 10.1016/j.joms.2009.09.057]

14. Brasileiro BF, Passeri LA. Epidemiological analysis of maxillofacial fractures in Brazil: a 5-year prospective study. Oral Surg Oral Med Oral Pathol Oral Radiol Endod. 2006 Jul;102(1):28-34. Epub 2006 Mar 22. [Medline: 16831669] [doi: 10.1016/j.tripleo.2005.07.023]

15. Motamed MH. An assessment of maxillofacial fractures: A 5-year study of 337 patients. American Association of Oral and Maxillofacial Surgeons, 2003 Jan;61(1):61-4. [Medline: 12524610] [doi: 10.1053/joms.2003.50049]

16. van den Bergh B, Karagozoglu KH, Heymans MW, Forouzanfar T. Aetiology and incidence of maxillofacial trauma in Amsterdam: a retrospective analysis of 579 patients. J Craniomaxillofac Surg. 2012 Sep;40(6):e165-9. Epub 2011 Sep 14. [Medline: 21917471] [doi: 10.1016/j.jcms.2011.08.006]

17. Walker TW, Byrne S, Donnellan J, McArdle N, Kerin MJ, McCann PJ. West of Ireland facial injury study. Part 1 . Br J Oral Maxillofac Surg. 2012 Oct;50(7):631-5. Epub 2011 Dec 20. [Medline: 22192609] [doi: 10.1016/j.bjoms.2011.09.025]

18. Al Ahmed HE, Jaber MA, Abu Fanas SH, Karas M. The pattern of maxillofacial fractures in Sharjah, United Arab Emirates: a review of 230 cases. Oral Surg Oral Med Oral Pathol Oral Radiol Endod. 2004 Aug;98(2):166-70. [Medline: 15316543 ] [doi: $10.1016 /$ i.tripleo.2004.01.020]

19. Sobreira T, Vieira JAO, Lobo AR, Wanderley JNB, Costa LJ. Prevalência de traumatismos bucomaxilofaciais em João Pessoa - Brasil. Rev Bras Cien Saúde. 2002;6(6):25-32.

20. Tong L, Bauer RJ, Buchman SR. A current 10-year retrospective survey of 199 surgically treated orbital floor fractures in a nonurban tertiary care center. Plast Reconstr Surg. 2001 Sep 1;108(3):612-21. [Medline: 11698831] [doi: 10.1097/00006534-200109010-00003]

21. Davidoff G, Jakubowski M, Thomas D, Alpert M. The spectrum of closed-head injuries in facial trauma victims: incidence and impact. Ann Emerg Med. 1988 Jan;17(1):6-9. [Medline: 3337417] [doi: 10.1016/S0196-0644(88)80492-X]

22. Valente R, Souza L, Antonini SV, Glock L, Castro Neto WN. Epidemiologia das fraturas mandibulares atendidas no Hospital da Santa Casa de Misericórdia de São Paulo (HSCSP) entre 1996 e 1998. Rev Bras Cir Period. 2003;2:141-6. 


\section{To cite this article:}

Scherbaum Eidt JM, De Conto F, De Bortoli MM, Engelmann JM, Rocha FD. Associated Injuries in Patients with Maxillofacial Trauma at the Hospital São Vicente de Paulo, Passo Fundo, Brazil.

J Oral Maxillofac Res 2013;4(3):e1

URL: http://www.ejomr.org/JOMR/archives/2013/3/e1/v4n3e1ht.pdf

doi: $10.5037 /$ jomr.2013.4301

Copyright $($ S Scherbaum Eidt JM, De Conto F, De Bortoli MM, Engelmann JM, Rocha FD. Published in the JOURNAL OF ORAL \& MAXILLOFACIAL RESEARCH (http://www.ejomr.org), 1 October 2013.

This is an open-access article, first published in the JOURNAL OF ORAL \& MAXILLOFACIAL RESEARCH, distributed under the terms of the Creative Commons Attribution-Noncommercial-No Derivative Works 3.0 Unported License, which permits unrestricted non-commercial use, distribution, and reproduction in any medium, provided the original work and is properly cited. The copyright, license information and link to the original publication on (http://www.ejomr.org) must be included. 